\title{
Exploring Connexion between Sovereign Wealth Funds and Islamic Finance in the Gulf Countries
}

\author{
Ashraf Mishrif ${ }^{1} \&$ Erhan Akkas² \\ ${ }^{1}$ Department of International Affairs, Qatar University, Qatar \\ ${ }^{2}$ Business School, Durham University, UK \\ Corresponding author: Ashraf Mishrif, Department of International Affairs, School of Arts and Sciences, Qatar \\ University, P. O. Box 2713 Doha, Qatar. Tel: 974-4403-7608. E-mail: ashraf.mishrif@gmail.com
}

Received: March 2, 2018

Accepted: March 27, 2018

Online Published: March 30, 2018

doi:10.5539/ijef.v10n5p75

URL: https://doi.org/10.5539/ijef.v10n5p75

\begin{abstract}
This study explores the relationship between the development of sovereign wealth funds (SWFs) and Islamic finance in the Gulf Cooperation Council countries. It argues that despite a simultaneous growth in both industries in the petrodollar era, there has been insignificant degree of complementary between them and the size of SWFs investments in Islamic finance is limited. Analysis attributes such divergence to the peculiarity of SWFs' objectives, decision-making and investment strategy. Islamic finance has yet to provide low-risk long-term investment opportunities that are more attractive to SWFs than that available in the conventional market, hence bringing the industry under the funds' radar. The study concludes by arguing that despite such limitation, both SWFs and Islamic finance have contributed to economic development and have the potential to overcome such lack of conjunction.
\end{abstract}

Keywords: Sovereign wealth fund, Islamic finance, GCC countries, investment strategy, risk management

\section{Introduction}

Since the mid-1970s, the surge in financial globalisation has produced a far-reaching structural and ideological transformation in the financial system. At the forefront of this transformation is the evolution of sovereign wealth funds (SWFs) and significant growth in the Islamic banking and finance industry. These newly developed financial settings are amongst the fastest growing industries in the Gulf region and globally. Gulf oil-producing countries have used their oil revenues as a mechanism to reconfigure their position in the global financial system through the creation of SWFs and boosting Islamic finance. By 2017, the member states of the Gulf Cooperation Council (GCC) - Bahrain, Kuwait, Qatar, Oman, Saudi Arabia and United Arab Emirates (UAE) - have accumulated assets and capital worth around US\$2.99 trillion, accounting for 40 per cent of total global assets managed by SWFs worldwide (SWFI, 2017). Meanwhile, analysis of Islamic financial data underlines the correlation between the rise in oil prices and the growth of Islamic finance in the GCC region (Mishrif, 2015). According to the World Islamic Banking Competitiveness Report 2016, GCC countries have played a prominent role in the development of Islamic finance, with these countries collectively accounting for over 47 per cent of global Shariah-compliant financial assets in 2014. This makes Islamic finance an attractive industry to major financial institutions such as Citi Group, HSBC, and Barclays Bank (Ernst \& Young, 2016).

Despite such simultaneous growth in SWFs and Islamic finance, there is no evidence of complementarity between the two industries or precise account of how and to what extent have SWFs contributed to the development of Islamic finance in the Gulf region. Existing literature examines each industry separately. Islamic finance literature focuses largely on the resilience of Islamic banks during the global financial crisis, while that concerning SWFs concentrates on issues relating to governance and transparency. This study aims to bridge this gap by exploring the factors that affect the relationship between these industries. It attempts to explain why despite the similarity in the economic and political conditions and the environment within which SWFs and Islamic finance evolved in the GCC region there is a higher degree of divergence than convergence between the two industries. To address this critical question, the study analyses four key factors that could facilitate or hinder the connexion between SWFs and Islamic finance. It evaluates the level of complementarity between the two industries; SWFs investment strategy and allocation of asset classes outside Islamic finance; concentration of SWFs investments in the real economy rather than moral economy; and their sensitivity to risk and risk 
management. As explained in the methodology section, we employ a multidisciplinary approach that allows for a comprehensive, in-depth analysis of the above factors, together with a combination of semi-structured interviews and statistical data on SWFs and Islamic finance from reliable sources. The study begins by providing a conceptual synopsis on SWFs and Islamic finance, followed by a literature review on the development SWFs and Islamic finance in the GCC countries. The following sections explain the methodology, data analysis and discussion on the key findings.

\section{Conceptualizing Sovereign Wealth Funds and Islamic Finance}

\subsection{Sovereign Wealth Funds}

SWF Institute defines SWF as a state-owned investment fund created from balance of payments surpluses, official foreign currency operations, proceeds of privatisations, government transfer payments and receipts from exports of natural resources such as oil and gas (SWFI, 2017). This type of fund is classified into five categories: stabilisation funds, savings (future generations) funds, pension reserve funds, reserve investment funds, and strategic development funds. These funds aim to stabilise the budget and protect the economy from excess volatility in export revenues, to diversify from non-renewable commodity exports, to earn greater returns on investment, to increase savings for future generations, and to fund economic development programmes.

Mainstream schools of thoughts such as Institutionalism, Neoliberalism and Marxism express differing perceptions on SWFs. Each theory approaches the subject from a different perspective. Institutionalists perceive SWFs from the perspective of governance or legitimacy and view them as the outcome of institutional innovation. They believe that SWFs have a role to perform in the domestic economy and global financial system (Monk, 2010; Feldstein, 2008). They argue that SWFs are instruments for financial governance because they are based on government structure and political legitimacy; hence, they are almost free of internal criticism in terms of investment policy formation and implementation. Globally, SWFs' legitimacy has been consolidated through their participation in the international financial markets, where SWFs transactions have been responsible for promoting growth, welfare and economic development in both capital exporter and host-countries (Monk, 2010; Dixon \& Monk, 2012).

Neoliberals view SWFs as facilitators of global integration. They argue that SWFs help to reduce the risks in global finance by helping to free up cash flows from states that have surplus budgets to those require liquidity and to balance the global financial system (Seznec, 2012). SWFs operate as investment vehicles, as well as protection against risk factors of the investment diversity. This is evident in the investment policies adopted by GCC SWFs in Europe and the US during the 2008 global financial crisis, with the aim of maximising returns on investment (Jen, 2008). Hanna (2008) argues that focusing on the liberalisation of the asset market, privatisation, and intensive-investment can help GCC countries to integrate further in the global financial system. However, neoliberalists retain some concerns about SWFs, particularly those relating to transparency, management and government financing (Reisen, 2008; Subacchi, 2008).

Marxists tend to focus on the impact of SWFs on class configuration and state-society relations in the GCC countries, rather than on the economic situation created by their investments. In the context of the GCC countries, Marxists argue that SWFs have instigated class formation, particularly where financialisation transforms Gulf societies into capitalist systems, comprising of royal family-based capital. Hanieh (2011) argues that the pattern of capital accumulation in the GCC region exemplifies a new set of internationalised social relations and represents a process of class formation described as 'Khaleeji Capital'.

\subsection{Islamic Finance}

The theory of Islamic finance derives its concepts and assumptions from the social, economic, historical and theological aspects of Islam. It is founded on the understanding of Tawhidi (Oneness); driven by Shariah, which is the religious law of Islam; and complied with the Qur'an and Sunnah (the guidance of the Prophet Muhammed) as primary sources of knowledge that guide Muslims to apply Islamic finance in their social and business practices (Chapra, 1992; Naqvi, 1995; Asutay, 2016). Iqbal and Mirakhor (2011) define Islamic finance as a discipline relating to the rules and behaviours of individuals and institutions, economic practices of these rules, and economic structure and policies that characterise an economic system ideated by Islam. Shariah prohibits riba (interest), gharar (gambling) and maysir (insubstantial economic activities). Islamic finance uses risk sharing and rewards financing modes rather than debt-based modes in order to guarantee justice between borrowers and lenders by distributing wealth through profit and lost sharing (Iqbal \& Mirakhor, 2011).

Islamic finance has expanded its transactional base and performance in Muslim and non-Muslim countries through its resilience and innovative products and services, hence permitting investors to benefit from these 
newly created financial opportunities (El-Gamal, 2006). Islamic financial products such as murabahah, takaful, ijarah, musharakah and sukuk are widely used in the Muslim countries, while attracting attention in Europe, Asia and the USA after introducing new regulations that facilitate the use of the Islamic financial products in their financial system (Al-Salem, 2009; UKTI, 2014). Although some Islamic products such as sukuk and takaful appear similar to conventional bond and insurance, these Islamic products are based on Shariah principles through Islamic epistemology.

It is also important to note that murabaha, musharakah, and Ijara are major Islamic financial instruments that are widely used in daily business practices. The definitions of these instruments vary according to the purpose of the instrument. Murabaha is an Islamic financing structure by selling a commodity to a customer with pricing of the cost of commodity and an agreed profit margin, instead of lending at interest that is prohibited in Islam. Musharakah is a partnership structure between the bank and a customer to a certain investment enterprise based on profit and loss sharing to avoid loans at interest. Therefore, the two parties are involved in a business by contributing to the real economic system directly in return of profit or loss. In this structure, financier is a part of investment rather than only financing. Ijara is an agreement based on leasing an asset to a customer for a specific time with a certain rent instalments. Ijara can end in a change of ownership of the asset to the lessee at the end of the lease period (Basov \& Bhatti, 2016; El-Gamal \& Eissa, 2003). Moreover, Islamic finance has experienced an expansion in the halal industry, with significant growth in halal economic activities such as tourism, trade, dinning and commerce that comply with Shariah rules. Such expansion and growth of Islamic investments across most economic sectors that exhibit moral and social responsibility have turned this industry into a unique phenomenon in the global financial system.

\section{Literature Review on the Development of SWF and Islamic Finance in GCC Countries}

Surveying literature in Gulf finance indicates that the Gulf countries have effectively used their financial surplus from oil revenues to develop their financial systems. At the forefront of this development is the creation of SWFs and development of the Islamic banking and finance industry. Although the economic conditions that led to the creation of both industries are synonymous, these industries have developed simultaneously since the early 1970s, but independently to achieve certain objectives and serve different sections in society. In relation to Gulf SWFs, the accumulation of wealth from oil revenues and the desire of the GCC countries to play a greater role in global financial markets have resulted in the creation of 14 SWFs in these countries. By mid-2017, GCC countries have accumulated around US\$2.99 trillion, accounting for almost 40 per cent of total global SWFs assets worldwide. Table 1 provides detailed account of these funds, including their values, source of capital and ranking regionally and globally. It underscores the prominent position of these funds and the extent to which they can influence the global financial system. Bazoobandi (2011) argues that GCC SWFs are effective tools for diversifying their national revenues and generate assets from their portfolio investments worldwide. Shabbir (2009) highlights the effective role of GCC SWFs in enabling their governments to resist market pressure during the global financial crisis, while providing capital by investing in many financial institutions and companies that were in need of liquidity nationally and globally. After the decline in oil prices in the mid-2014, these funds have been instrumental in supporting the current accounts of their countries and rebalancing their income distribution, while serving as long-term investments to support the implementation of national development plans.

Table 1. Sovereign wealth funds in the GCC countries, 2017

\begin{tabular}{llccccc}
\hline Country & Holding Funds & $\begin{array}{c}\text { Year } \\
\text { Created }\end{array}$ & $\begin{array}{c}\text { Total Capital } \\
\text { (US\$ bn) }\end{array}$ & $\begin{array}{c}\text { Source of } \\
\text { Funding }\end{array}$ & $\begin{array}{c}\text { GCC } \\
\text { Ranking }\end{array}$ & $\begin{array}{c}\text { Global } \\
\text { Ranking }\end{array}$ \\
\hline UAE & Abu Dhabi Investment Authority & 1976 & 828 & oil & 1 & 2 \\
& Investment Corporation of Dubai & 2006 & 200.5 & non-commodity & 5 & 11 \\
& Mubadala Development Company & 2002 & 125 & oil & 7 & 14 \\
& Abu Dhabi Investment Council & 2007 & 110 & oil & 8 & 15 \\
& Emirates Investment Authority & 2007 & 34 & oil & 9 & 27 \\
& Ras Al-Khaimah Investment Authority & 2005 & 1.2 & oil & 13 & 60 \\
Saudi & Sharjah Asset Management & 2008 & na & non-commodity & 14 & 79 \\
Arabia & PAMA Foreign Holdings & 1952 & 514 & oil & 3 & 5 \\
Kuwait & Kuwait Investment Authority & 2008 & 183 & oil & 6 & 1 \\
Qatar & Qatar Investment Authority & 2005 & 324 & oil & 2 & 4 \\
Oman & State General Reserve Fund & 1980 & 18 & oil \& gas & 4 & 9 \\
& Oman Investment Fund & 2006 & 6 & oil \& gas & 10 & 31 \\
Bahrain & Mumtalakat Holding Company & 2006 & 10.6 & oil & 12 & 38 \\
\hline
\end{tabular}

Source: SWF Institute, June 2017. 
The institutionalisation of Gulf finance is evident in the systematic way in which GCC SWFs created. The early realisation of the depleted nature of oil and importance of investing its revenues for future generations resulted in the creation of the first generation of funds in the region, including SAMA Foreign Holdings in 1952, the Kuwait Investment Authority in 1953, Abu Dhabi Investment Authority in 1976, and Oman State General Reserve Fund in 1980. Between 2005 and 2008, a second generation of funds was created, with Qatar establishing Qatar Investment Authority in 2005 and Bahrain establishing Mumtalakat Holding Company in 2006. During this period, Saudi Arabia, Oman and UAE created addition funds (see table 1). The third generation of funds is more complex and transparent, and intended to contribute directly to the economic development of their countries. The structure and objective of this type of funds are still not clear as Saudi Arabia has yet to build a new SWF with new mandate. In 2017, Saudi Arabia announced its intention to establish a new SWF that is transparent in setting up its investment strategy and operations. Saudi Crown Prince Mohammed bin Salman argues that his country is getting ready for post-oil era by creating the largest SWF globally, with an estimated capital of US\$ 2 trillion, while privatising partially the Saudi Arabian Oil Company (Aramco) by end of 2018. Micklethwait et al (2016) argue that these funds can play a key role in economic development and investment nationally and internationally.

Moreover, GCC funds have gone through intensive internal restructuring in terms of management and operations, as well as creating and developing their own regulatory system for monitoring their investment activities. For instance, Qatar issued the Emiri decree No. 22 of June 2005 to define the legal framework and governance structure of its fund. Qatar Investment Authority (QIA) confirms its compliance and implementation of Santiago Principles, by stating that "from the beginning, legal and governance frameworks were clearly defined in order to support QIA's initial investment strategy focused on domestic equity and regional investment and a significant allocation to external managers globally" (QIA report, 2008). This statement is echoed by Hamed bin Zayed Al Nahyan, managing director of Abu Dhabi Investment Authority (ADIA), who argues that ADIA has made significant steps towards developing its domestic capabilities and increasing its internal flexibilities to adjust to new market conditions and maximise its effectiveness and ability to seize investment opportunities (ADIA, 2016). Such statements underline the commitment of GCC SWFs to national development and stability of the global financial system, which requires greater degree of compliance with international rules as stated in the Santiago Principles. In terms of national development, a study by Invesco (2012) notes a substantial shift in the investment strategy of GCC SWFs towards domestic markets in post-Arab spring. A few years later, Mishrif (2015) underscored the engagement of GCC SWFs in public investment in infrastructure, healthcare and education; these investments increased in terms of assets from 33 per cent to 56 per cent and in investment in local bonds from 6 per cent to 14 per cent in the GCC countries.

As for Islamic finance, the accumulation of wealth from oil revenues has also helped in creating a large number of Islamic banks, including Dubai Islamic Bank (1975), Islamic Development Bank (1975), the Kuwait Finance House (1977), the Bahrain Islamic Bank (1978), the Islamic Investment Company of the Gulf in Sharjah (1978), and the Bahrain Islamic Investment Bank in Manama (1980). By 2010, shariah-compliant banking assets represented a significant portion of total banking assets in the GCC countries, with Saudi Arabia accounting for 35 per cent (US $\$ 377$ billion), Kuwait 31 per cent (US\$155 billion), Bahrain 27 per cent (US\$46 billion), Qatar 22 per cent (US $\$ 156$ billion), and UAE 17 per cent (US $\$ 438$ billion). This significant growth has made the GCC the largest regional market for Islamic banking and finance, higher collectively than other regional markets such as Malaysia and Turkey, whose shares stood at 17.3 per cent (US\$505 billion) and 4.3 per cent (US\$652 billion), respectively (Ernst \& Young, 2016).

Table 2. Distribution of Islamic finance assets in GCC countries, 2012-2016 (US\$ bn)

\begin{tabular}{ccccc}
\hline & Banking Assets & Sukuk Outstanding & Islamic Mutual Funds & Takaful Contribution \\
\hline 2012 & 434.50 & 66.30 & 28.90 & 7.20 \\
2013 & 490.30 & 74.90 & 35.90 & 7.60 \\
2014 & 564.20 & 95.50 & 33.50 & 9.000 \\
2015 & 598.80 & 103.70 & 31.30 & 10.40 \\
2016 & 650.8 & 115.2 & 23.4 & 11.7 \\
\hline
\end{tabular}

Source: IFSB Reports, 2015-2016-2017.

Mishrif (2015) argues that the institutionalisation of Islamic finance through wide-ranging policies on legislation and regulations has facilitated the growth and development of the Islamic finance industry. This led to substantial growth in sukuk and takaful, although Islamic banks still lag behind in personal banking in some GCC countries (Wilson, 2009). Table 2 shows a substantial growth in Islamic financial assets, particularly banking assets and 
sukuk between 2012 and 2016. Mullaly (2016) indicates that such rise in Islamic assets underlines a growing trend towards diversifying Islamic investment in key economic sectors in order to pave the way for the full potential of Islamic economy.

The above analysis correlates the qualitative data with the quantitative data collected on the growth of SWFs and Islamic finance in the GCC region and globally. Figure 1 confirms a steady growth in both industries between 2006 and 2016. However, one has to stress that national identity and religion embedded in the Gulf social and economic system have played a role in the expansion of Islamic finance, while the abundance of wealth and political support have given rise to SWFs in the Gulf region. What concerns us here is how and to what extent have SWFs contributed to the development of Islamic finance, and broader economy, in this region.

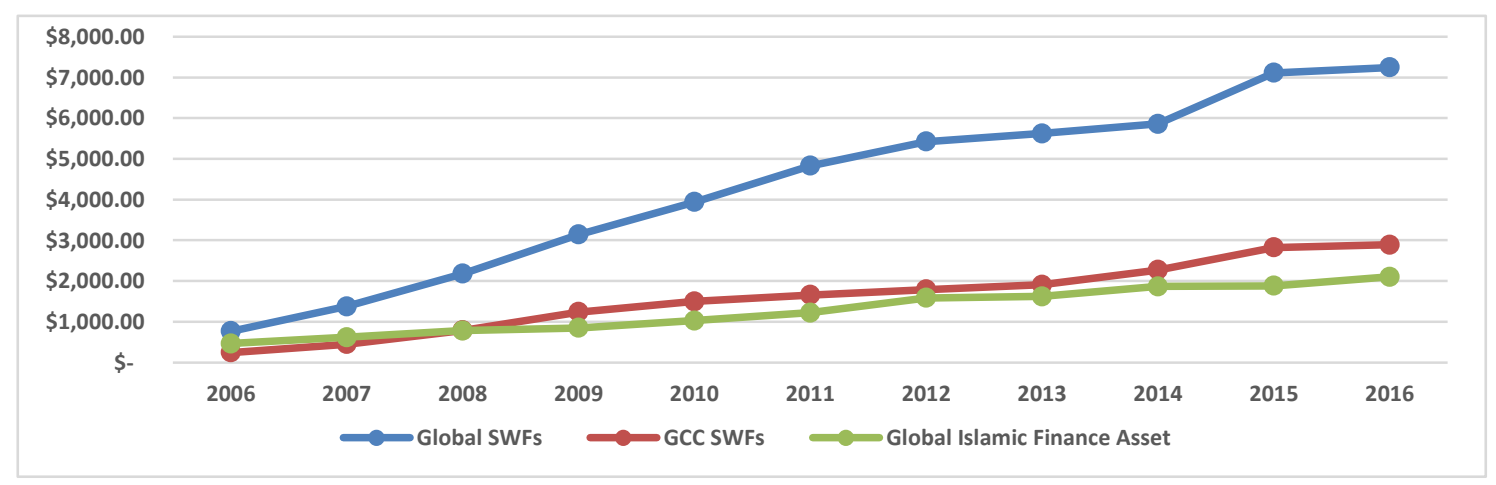

Figure 1. SWFs and Islamic finance 2006-2016 (US\$ bn.)

Source: SWFs Institute 2016; IFSB Report 2015-2016.

*Figures on GCC Islamic assets are not available between 2006 and 2011.

\section{Hypothesis and Methodology}

The above literature review indicates that both SWFs and Islamic finance have developed independently in the Gulf countries over the past fifty years. To examine the effect of one industry on the other, the study has to explore the intersection and levels of interaction between the two industries, given the fact that both of them have developed at the same time and in the same region. It puts forward a number of hypotheses to test in order to come with a reasonable explanation. The first hypothetical factor is the low level of investments by SWFs in the Islamic finance industry. For the purpose of clarity, this study limits its analysis to the meaning of SWFs as defined above, and not considering any investments made by governments, which could also be sovereign.

\section{H1: There is a weak complementarity between SWFs and Islamic finance.}

The second hypothesis is low priority of Shariah-compliant assets on SWFs investment agenda, indicating that they are not as attractive to SWFs as conventional assets.

\section{H2: The majority of SWFs asset classes allocated outside Islamic finance.}

The third hypothesis is the concentration of SWFs investments in real economy because these funds do not have mandates to promote Islamic finance.

\section{H3: SWFs invest in real economy rather than moral economy.}

The fourth hypothesis is the sensitivity of SWFs and Islamic finance to the risks associated with their investment operations in national and international markets.

\section{H4: SWFs and Islamic finance are sensitive to risk and risk management.}

In order to test the above hypotheses, this study focuses on the factors that facilitate or hinder the intersection between SWFs and the Islamic finance industry. It adopts an interdisciplinary approach that combines an exploratory descriptive case study approach to provide detailed examination of SWFs and Islamic finance in GCC countries and an interpretive approach as a research philosophy to explore the extent to which have these countries developed their Islamic finance industry through SWFs. The justification of such approach is illustrated by Wester (1995), who argues that effective use of grounded theoretical approaches such as exploration and specification can help in creating a fundamental relationship between data collection and analysis. The rationale of selecting GCC countries as empirical case study is threefold. First, despite the significant growth in SWFs and Islamic finance between 2008 and 2016, no serious examinations have yet been 
conducted to examine the relationship between the two industries. Second, GCC countries are home of 14 of the world largest SWFs and currently possess around 40 per cent of global SWFs assets. Third, GCC countries collectively account for around 47.6 per cent of the US $\$ 2.1$ trillion of total global Islamic financial assets. This makes the GCC region a natural home for both industries.

This study draws on both primary and secondary sources. It uses a combination of qualitative and quantitative techniques to explore opinions and perceptions of key stakeholders concerned with SWFs and Islamic finance across the region (Neuman, 2015). It surveys government publications and financial reports. Saunders et al. (2009) also stress the importance of interviews as effective tools to explore and extract confidential information from industry experts to provide better understanding of the variables under consideration. A set of semi-structured interviews are conducted with 20 industry experts and executives, who work across the GCC region and are authoritative on the subject. Some of the industry experts interviewed have had the privilege of working closely with both SWFs and Islamic finance. Moreover, we extracted significant amount of quantitative data from several databases, including SWF Institute database, the World Bank database, annual reports and press releases from banks and companies such as the Gulf Investment Corporation (GIC). On Islamic finance, we source most quantitative data from company databases and websites, as well as annual reports and press releases. However, due to sensitivity and non-disclosure nature of their work, the majority of SWFs executives insisted on concealing their identities and affiliations. This explains the limited number of interviews and reluctance of officials to provide detailed information.

\section{Data Analysis and Discussion}

This section categorises the data collected from primay and secondary sources in a way that answers research question and test hypotheses. This section examines the following aspects: the position of SWFs in promoting Islamic finance; SWFs investment strategies and their allocation of asset classes in Islamic finance; capacity of Islamic finance to attract investment from SWFs; and sensitivity of SWFs to risk and risk management in decision-making and operations.

\subsection{Weak Complementarity between SWFs and Islamic Finance}

Data analysis reveals a weak complementarity between SWFs and Islamic finance. Chief amongst the main causes of this weak relationship is the differing objectives and motivations of SWFs from that of their governments in promoting and investing in Islamic finance. According to SWF executive in the Gulf region, SWFs are assigned with the task of preserving the wealth of the state. Although they are state-owned financial institutions, SWFs operate as private entities and mainly run by western financial experts, who are not knowledgeable or have experience in Islamic finance. These executives are accountable to the ministry of finance and have to show a positive balance sheet at the end of the year. Thus, the objectives of SWFs are to preserve wealth, mitigate risk and maximise profits. According to a former CEO of one of GCC SWFs, SWFs do not have mandates from the state to promote or invest in Islamic finance, hence eliminating the possibility of political interference or obligations to invest in Islamic finance (interview, May 2017).

Meanwhile, GCC governments have incentives to promote Islamic finance because their constitutions are based on Islamic rules. Bernard Barbour, Managing Director and Head of Legal and Shariah Affairs in QINVEST (2017) argues that although all GCC countries run a dual system, conventional and Islamic, their governments see Islamic finance as "a privilege of the state" because it provides them with new Shariah-compliant financial products and services that appeal to most consumers in the Muslim conservative Gulf society. Governments issue sukuk, when they engage in mega projects, particularly when economic conditions in the conventional markets do not allow for issuing bonds. Islamic finance may also serve as a catalyst to enhance the competitive advantage of GCC countries vis-à-vis Malaysia in their struggle for global leadership.

However, analysis reveals a few exceptions to this rule, including the investment of Qatar Investment Authority (QIA) in Hassad Food, an Islamic company operating the agriculture sector. Al Rawabi, which operates in the food industry in UAE also received fund from the Investment Corporation of Dubai (ICD), the second largest SWF in UAE and fifth largest in the GCC region. Although these investments are made in Islamic compaies, our data shows that the aim of these investments is not to promote Shariah-complaint products, but are made in companies that are Islamic by definition. In Barbour's view, this is a pure luck, rather than a deliberate action. This perception is confirmed by Hamad Al Saad, senior advisor to the CEO of Hassad Food, who argues that the creation of Hassad Food in 2008 is part of a wider GCC strategy aimed at importing essential goods and investing in food security in Africa and the Middle East. These investments are driven by necessity to fulfil government objectives while adopting the commercial management style of SWFs that aims at maximising profits. 
One has to distinguish between the management style and decision-making process in government and SWF in order to explain how each affects the levels of investment in Islamic finance. At the government level, investment in Islamic finance is made by a political decision that takes into account a wide range of factors such as job creation, promoting certain values, meeting the demands of the internal market, and supporting ethnic groups in society. In such case, profitability is not the only factor that determine the decision of whether or not to invest in a given project. At the SWF level, the Board of Directors takes into account the risk factor and higher returns on investment in investment decisions; hence, management style, rather than culture or religion, governs SWF decision-making process. This is evident in the management style and structure of almost all GCC SWFs, which focus solely on achieving sustainable-adjusted financial returns on their investments. The case of QIA demonstrates a complex investment framework and decision-making process, in which the fund develops its investment strategies and risk management nationally and globally. Thus, our analysis attributes the success of QIA in increasing the fund's portfolio since 2005 to its effective decision-making process. This complex, cautious management style and four-stage decision-making process (orientation, evaluation, execution, management) force QIA to focus on investments that allow for taking advantage of long-term market trends and development, rather than short term high-risk high-profit investments.

\subsection{SWFs Investment Strategy and Asset Classes Allocation outside Islamic Finance}

Analysis reveals that SWFs have unintentionally ignored Shariah-compliant assets and that Islamic finance has not been a priority in their investment strategies. Figure 2 shows that SWFs investment in equity accounted for 53 per cent of total SWFs assets in GCC countries between 2005 and 2011.This is followed by fixed income at 20 per cent and real estate at 13 per cent. The alternative, which includes private equity fund participations and investment in hedge funds and infrastructure, accounts for 8 per cent of the total portfolio in the same period (European Investment Bank, 2013). Surprisingly, the remaining 6 per cent includes some newly developed industries such as Islamic banking and the halal industry, where SWFs use Shariah-compliant financial tools and Islamic business with its foreign investment. Some analysts, however, argue that sukuks could be included in fixed income, but no breakdown data is available on this type of assets.

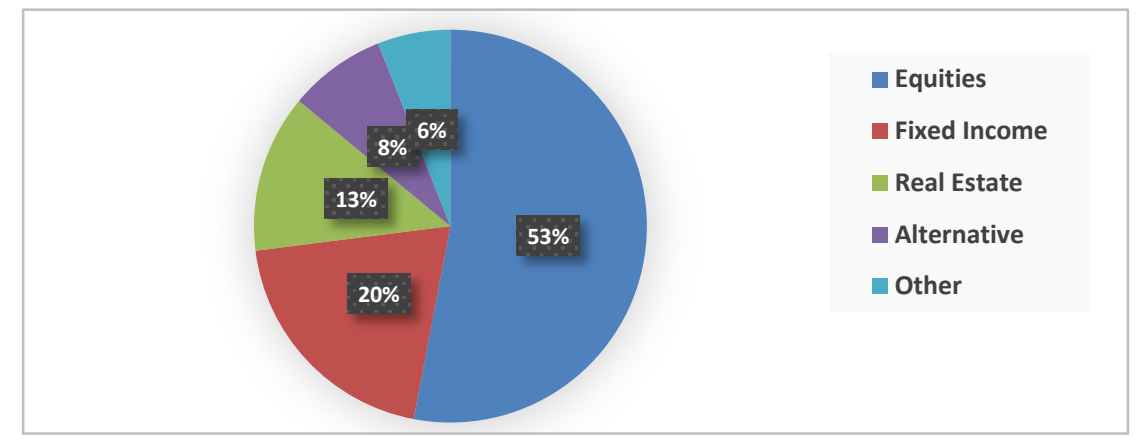

Figure 2. GCC SWFs portfolio allocation across asset classes, 2005-2011

Source: SWF Institute and European Investment Bank, 2012.

In terms of their investment strategy, SWFs operate as commercial entities and driven by profitability. They allocate their investments in highly secured long-term investments. These characteristics mark the diversification of the portfolio of Abu Dhabi Investment Authority (ADIA) - the largest SWF in the entire GCC region - across over 20 asset classes and sub-categories. Data shows that the share of developed equities ranges between 32 per cent and 42 per cent of total investment by asset. Emerging market equities and government bonds occupy the second and third positions; each class has assets ranging between 10 per cent and 20 per cent, respectively. Credit, alternative and real estate assets are less attractive, with each asset ranging between 5 per cent and 10 per cent. Investments in private equity and infrastructure assets range between 2 per cent and 8 per cent and 1 per cent and 5 per cent, respectively. The concentration of the majority of investments in less-risky asset classes such as developed and emerging market equities and government bonds confirms ADIA's sensitivity to risk management (ADIA, 2017).

When analysing the portfolio by region, data shows that ADIA concentrates the majority of its investment in North America and Europe, which attract between 35 per cent and 50 per cent and 20 per cent and 35 per cent, respectively. Developed Asia and emerging markets attract together between 25 per cent and 45 per cent of total investment in 2016. ADIA has no appetite for investing in high-risky developing country markets (ADIA, 2017). 
These statistics also validate the qualitative data, which confirms that "90 per cent of GCC SWFs' assets are located outside the Gulf region because of the undeveloped nature and small size of their markets" (interview with Al Saad, May 2017). The categorisation of QIA asset classes is another example of inattention of Islamic finance. Although a number of reports published in 2015 by ESADE, KPMG, Invest in Spain, and ICEX underscore a great potential of rise in SWF investment in Islamic vehicles, the categorisation of asset classes does not have a specific category for Islamic equities or funds. This may underline lack of expertise, inexperience of the fund executives in Islamic finance, and possibly unfamiliarity of QIA with the Islamic finance industry.

\subsection{SWFs Invest in Real Economy, Not Moral Economy}

Surveying the 14 SWFs in GCC countries shows that only Abu Dhabi Investment Council (ADIC) and the Mubadala Development Company in UAE have mandates to contribute to their home country economic development. ADIC adopts an investment strategy that spreads risk-adjusted returns across the entire capital structure and concentrates on investments that add value to Abu Dhabi's economy through active investments, equities, fixed income, infrastructure, natural resources, real estate, and private equity. Some investments at stakes comprise of National Bank of Abu Dhabi, Abu Dhabi Commercial Bank, Al Hilal Bank, Abu Dhabi National Insurance Company, Abu Dhabi Investment Company, and Abu Dhabi Aviation Company.

Similarly, Mubadala has a mandate to contribute to the development of Abu Dhabi through large investments in aerospace, capital market, defence services, healthcare, ICT, metals and mining, oil and gas, real estate, infrastructure, renewables, and utilities. Even when investing globally, Mubadala focuses on the capital market, semiconductors (US, Germany, and Singapore), real estate, infrastructure (US), aerospace (Italy and Switzerland), renewables (Spain and UK), and utilities (Algeria and Oman). None of these investments has aimed at supporting Islamic economy; rather they aimed at seeking collaboration with global partners in order to create high-class investment portfolio across multiple sectors for Abu Dhabi.

When examining the overall portfolio investments of the 14 SWFs in the GCC, statistics reveal that the majority of their funds have been invested in real economy. Table 3 illustrates the distribution of GCC SWFs by sector between 2005 and 2015. The financial sector, real estate, infrastructure, energy and industry attracted the majority of funds, with substantial investments also made in the ICT sector and healthcare.

Table 3. Distribution of GCC SWFs investment by Sector 2005-2015 (US\$ m)

\begin{tabular}{lccccccc}
\hline & Energy & Financials & Healthcare & Industry & IT & Infrastructure & Real Estate \\
\hline 2005 & 182.60 & 21.6 & 13.15 & 112.10 & - & - & $1,109.0$ \\
2006 & 383.22 & 270.57 & - & 289.36 & - & - & $4,808.2$ \\
2007 & $5,207.7$ & $9,202.1$ & 546.56 & 161.62 & 824.08 & - & $2,686.3$ \\
2008 & $1,116.7$ & $20,155.55$ & 151.46 & 252.83 & 241.02 & $2,963.66$ & $9,311.2$ \\
2009 & $6,050.5$ & $2,851.18$ & - & $17,667.36$ & 540.78 & $14,611.35$ & $1,722.3$ \\
2010 & 440.92 & $15,993.62$ & 199.13 & $1,707.35$ & $1,208.22$ & $1,553.30$ & $1,562.9$ \\
2011 & $5,421.4$ & $5,794.46$ & - & 120.42 & 14.63 & $1,586.32$ & $3,283.5$ \\
2012 & $4,803.9$ & 616.56 & 87.89 & 387.06 & 884.74 & $2,446.75$ & $3,346.5$ \\
2013 & 310.16 & $2,513.99$ & 163.53 & 864.84 & 942.21 & $1,287.23$ & $9,619.08$ \\
2014 & 305.16 & $1,173.85$ & 559.57 & 259.70 & 358.66 & $5,534.67$ & $12,134.42$ \\
2015 & 219.56 & 273.68 & 56.63 & 12.95 & 221.47 & $3,534.96$ & $6,621.13$ \\
\hline
\end{tabular}

Source: GIC Report 2015.

Although table 3 does not show any significant investment in Islamic finance, there has been few investments made by ICD and ADIC in Islamic banking. Of all investments made in 2015, only two sizable investments made by ICD in Islamic banking by acquiring 56 per cent stake in Emirates NBD, making it the largest stakeholder, and 27.9 per cent stake (1.103.699.720 shares) in Dubai Islamic Bank. ADIC, which made significant investments in conventional banking, acquired only 7.6 per cent stake in Abu Dhabi Islamic Bank (ESADE Report, 2015). Apart from acquiring Hassad Food in 2008, QIA did not report any substantial investments in Islamic finance until 2015. Data shows that QIA invests the majority of its capital across various industries, including real estate, finance, aviation, automotive, sports, culture, media and tourism. However, QIA made limited contribution to Islamic finance with the acquisitions of 17 per cent equity (25.680.763 shares) in Qatar International Islamic Bank, 16.7 per cent in Qatar Islamic Bank, and 11.9 per cent stake in Masraf Al Rayan in 2015 (ESADE, 2015). These banks concentrate their operations in the domestic market. However, some Qatari banks such as Qatar National Bank (with its Al Islami subsidiary), Commercial Bank of Qatar (with 
its Al Safa Islamic Banking subsidiary), and Doha Bank (with its Doha Islamic Bank subsidiary) established Islamic affiliates to diversify risks and expand in foreign markets, including Lebanon, Yemen, Kazakhstan, Turkey, Egypt, UK, Saudi Arabia and Bahrain.

There is no available data on the contribution of Kuwait Investment Authority (KIA) and Saudi Arabian Monetary Agency (SAMA) in the development of Islamic finance, but both have invested in a variety of asset classes from equities and bonds to private equity, real estate and infrastructure in the international market. Oman State General Reserve Fund (SGRF) concentrates its investments in real estate, private equity, public market, joint ventures, and local initiatives. It focuses largely on public market assets (tradable) such as equity, fixed income bonds and short-term asset, and on private markets assets (non-tradable) such as private investment in real estate, logistics services, and commercial and industrial projects. When looking at private equity, SGRF targets sectors such as mining, healthcare, food, agriculture, transport, logistics and co-investment in foreign markets in order to create sustainable economic opportunities for Oman. Moreover, SGRF investments in international joint venture projects aim at contributing to the development of Omani economy. For example, Vietnam Oman Investment (founded in 2008), Oman India Joint Investment Fund (founded in 2011) Uzbek Oman Investment Joint Venture (founded in 2010), and Oman Brunei Investment Company aim to diversify SGRF investment portfolio in foreign markets (SGRF, 2017). Oman Investment Fund (OIF) invests in sectors such as travel and leisure, media, entertainment, financial services, telecommunication, and industry.

Bahrain Mumtalakat Holding Company is the smallest SWF in GCC countries in size and value, but it is one of the most active and diversified funds in the region. It fulfils its long-term objective of increasing the value of its portfolio by investing in domestic, regional and international markets. Mumtalakat enters into partnerships with national and foreign companies in sectors such as logistics, consumer and healthcare, general services, financial services, industrial manufacturing and services, real estate, tourism, telecommunication, technology and media (Mumtalakat, 2017).

This survey reveals that SWFs play a much greater role in the development process that goes beyond traditional methods of savings and investment in Treasury bills. They help in diversifying Gulf economies, which are still dependent on the hydrocarbon sector, by investing in strategic sectors such as finance, banking, technology, manufacturing, transportation, education, infrastructure and real estate (Ramady, 2014).

\subsection{SWFs, Islamic Finance and Sensitivity to Risk and Risk Management}

Our data reveals contradicting perceptions on risk and risk management by SWFs and Islamic finance. One would expect that the Shariah principle of sharing profits and loses makes Islamic finance an attractive and safe industry for SWFs investments. Our data shows that this is not the case, as most SWF investments in Islamic finance are very small and limited to the banking sector. Our analysis identifies four factors that discourage SWFs from investing in Islamic finance.

First, SWFs executives believe that Islamic finance is not as rooted in the economic system in the same way affecting the lives of people, banks and institutions as conventional finance. Contrary to the Islamic financial system, the capitalist financial system has developed over the past five or six hundred years and produced a benchmark of errors that provide a relatively high degree of predictability, which enables financial institutions to make long-term investment plans. This is not possible in the case of Islamic finance that is almost a 40-year old and has passed only one major financial crisis. Barbour (2017) argues that although Islamic finance performed well during the 2008 financial crisis, there are insufficient data and studies to convince SWFs executives that Islamic finance is stable in the long run.

Second, there is a causal relationship between the growth in Islamic finance and increase in oil prices. Ahmed and Alrashidi (2015) find that oil prices do not cause changes in Islamic mutual fund performance in general; but, when it comes to major oil-exporting countries "oil is a key commodity that plays a central role in the economies of the Middle Eastern countries; hence, any changes in the price of oil will have a significant effect on them". When oil prices decline, investors may consider not investing in Islamic mutual funds. This perception is echoed by experts in Islamic finance, who experienced slowdown in the performance of Islamic investments in the GCC countries after the fall of oil prices in the mid-2014 (interview with Barbour, May 2017). Such correlation between oil prices and Islamic finance performance makes this industry unsustainable and unattractive in the eyes of SWFs executives.

Third, SWF executives are driven by profitability, making them reluctant to take risk or bear responsibility for making losses. SWFs have a clear direction, and no executive or Board of Directors would risk investing in costly projects or bear the legal risk in case of running into difficulties or disputes. As for Islamic finance, industry experts argue that Islamic finance is more expensive and risky than conventional finance (interviews 
with Barbour, May 2017; Al Saad, May 2017). This view cannot be generalised as QIA has taken sufficient measures to ensure that Hassad Food operates in accordance with SWF rules and regulations and that returns on investment are higher than those offered by banks. Al Saad (2017) confirms this position by arguing that the prices of Shariah-compliant products are higher by a margin of 20-30 per cent than their conventional counterparts. In such case, the company transfers the price difference to consumers, who are happy to pay a premium for the brand name or the halal product.

Fourth, the weak legal and regulatory system discourage SWFs to invest in GCC countries. A senior advisor to an investment company argues that the weak regulatory framework and lack of law enforcement distort the business environment and discourage both foreign companies and SWFs to invest in the Gulf markets. When compared to developed country regulatory systems, Gulf policies and regulations are vague, confusing and have too many loopholes. This is a risk environment for SWFs that do not have the luxury, the time or resources to waste in legal disputes, especially when such disputes could lead to the disclosure of their concealed investment strategies and operations in public domain. Moreover, despite the efforts made by the International Islamic Liquidity Management Corporation and the Islamic Fiqh Academy in regulating and producing innovative products and services, Islamic finance is much smaller and less regulated industry when compared to conventional finance. For SWFs, sensitivity to risk is a major issue because Islamic finance risk is a multiple factor that involves country risks, market risks, industry risks, credit risks, liquidity risks and operational risks, to name but a few.

\section{Conclusion}

This study explains the factors that affect the relationship between SWFs and Islamic finance in the GCC countries. It presents its analysis within the context in which the accumulation of wealth from oil revenues has facilitated the development of both industries over the past fifty years. Analysis reveals that these industries have developed independently and yet failed to create synergies for complementarity between them. The findings of the study confirm the hypotheses set out in this study and corresponds with previous studies in the subject area. The four hypotheses indicate that SWFs have not contributed to the development of Islamic finance because of absence of a clear mandate to promote Islamic finance, objectives and management style of SWFs, and their sensitivity to risk and risk management. These factors may have hindered the possibility of convergence between these two financial settings.

The findings of this study make significant contribution to literature, particularly improving understanding of the connexion between SWFs and Islamic finance. The examination of the effect of SWFs on the development of Islamic finance also fills a significant gap in literature. It provides new insights and improves understanding of the factors discouraging SWFs from investing equitably in Islamic finance. It differentiates between the positions of SWFs from those of governments in relation to Islamic finance, as well as highlighting the distinctive characteristics of each industry on conceptual and operational grounds. The findings underline the emerging role of SWFs in economic development and their potential to expand their operations beyond Islamic banking to include strategic areas such as the halal industry, agribusiness and food security.

The study recognises its limitations in both analytical and methodological terms. At the analytical level, the study explores the factors dispiriting SWFs from investing in Islamic finance, but it does not raise the question of why Islamic finance fails to attract investments from SWFs. A comprehensive study is needed to examine the capacity of Islamic finance to address the concerns of SWFs and to provide more attractive business opportunities that would encourage SWFs to add Islamic finance to their portfolio. Methodologically, the study could have benefited from more interviews and data on SWFs to allow for diverse views on the subject.

\section{Acknowledgment}

The initial idea of this paper was presented at the Gulf Research Meeting 2016 at the University of Cambridge, UK.

\section{References}

Abu Dhabi Investment Authority [ADIA]. (2016). Abu Dhabi Investment Authority Marks 40th Anniversary. Retrieved from http://www.adia.ae/En/pr/ADIA_40th_Anniversary_Open_Letter_Press_Release_English.pdf

Ahmed, M., \& Alrashidi, F. (2015). The relationship between Islamic mutual funds and oil prices: Which leads the other. ISRA International Journal of Islamic Finance, 7(2), 30-51.

Al-Salem, F. (2009). Islamic Financial Product Innovation, International Journal of Islamic and Middle Eastern Finance and Management, 2(3), 187-200. https://doi.org/10.1108/17538390910986326 
Asutay, M. (2016). Defining and framing Islamic economics as Islamic moral economy: An attempt to embed public policy in Islamic economics to generate emergence science. Journal of Islamic Economics and Finance, 5(2), 103-123. https://doi.org/10.22373/share.v5i2.1241

Basov, S., \& Bhatti, M. I. (2016). Islamic finance in the light of modern economic theory. New York: Springer. https://doi.org/10.1057/978-1-137-28662-8

Bazoobandi, S. (2011). Political economy of the Gulf sovereign wealth funds: A case study of Iran, Kuwait, Saudi Arabia and United Arab Emirates (Doctoral thesis). University of Exeter, Exeter, UK.

Chapra, M. U. (1992). Islam and the economic challenge. Leicester: Islamic Foundation.

Dixon, A. D., \& Monk, A. H. (2012). Rethinking the sovereign in sovereign wealth funds. Transactions of the Institute of British Geographers, 37(1), 104-117. https://doi.org/10.1111/j.1475-5661.2011.00447.x

Dubai Islamic Bank. (n. d.). Ownership. Retrieved from http://www.dib.ae/investor-relations/company-information/ownership

El-Gamal, M. (2006). Islamic Finance. Cambridge: Cambridge University Press. https://doi.org/10.1017/CBO9780511753756

El-Gamal, M., \& Eissa, M. (2003). Financial transactions in Islamic jurisprudence. Beirut, Lebanon: Dar al-Fikr.

Emirates NBD. (n. $\quad$ d.). Ownership Statistics. Retrieved from http://www.emiratesnbd.com/en/investor-relations/shareholder-information/ownership-statistics/

Ernst, \& Young. (2016). World Islamic Banking Competitiveness Report 2016: New Realities and New Opportunities. Retrieved

from http://www.ey.com/Publication/vwLUAssets/ey-world-islamic-banking-competitiveness-report-2016/\$FILE /ey-world-islamic-banking-competitiveness-report-2016.pdf

ESADEgeo. (2013). Sovereign Wealth Funds Report 2013. Retrieved from http://itemsweb.esade.edu/research/esadegeo/ESADEgeoSWFReport2013.pdf

ESADEgeo. (2014). Sovereign Wealth Funds Report 2014., Retrieved from http://itemsweb.esade.edu/wi/Prensa/SWF2014_ENG.pdf

ESADEgeo. (2015). Sovereign Wealth Funds Report 2015. Retrieved from http://www.investinspain.org/invest/wcm/idc/groups/public/documents/documento/mde2/nje5/ edisp/doc20 16619757.pdf

European Investment Bank. (2013). Mobilizing the potential of GCC sovereign wealth funds for Mediterranean partner countries (Reference Code: TA2011020R0FTF). The Boston Consulting Group. Retrieved from http://www.eib.org/infocentre/publications/all/femip-study-potential-of-gcc-sovereign-wealth-funds.htm

Feldstein, M. S. (2008). Resolving the global imbalance: The dollar and the U.S. saving rate. The Journal of Economic Perspectives, 22(3), 113-126. https://doi.org/10.3386/w13952

Gulf Investment Cooperation. (2015). Annual Report and Accounts 2015. Retrieved from http://www.gic.com.kw/wp-content/uploads/2016/07/annual_report_en2015_web.pdf

Hanieh, A. (2011). Capitalism and class in the Gulf Arab states. New York: Palgrave Macmillan. https://doi.org/10.1057/9780230119604

International Forum of Sovereign Wealth Funds [IFSWF]. (2014). International Forum of Sovereign Wealth Funds Santiago Principles: 15 Case Studies. London: IFSWF.

Invesco. (2012). 2012 Invesco Middle East Asset Management Study. Retrieved from https://www.cfasociety.org/uae/Documents/2012\%20IMEAMS\%20report.pdf

Iqbal, Z., \& Mirakhor, A. (2011). An introduction to Islamic finance: theory and practice. Hoboken: Wiley. https://doi.org/10.1002/9781118390474

Islamic Financial Services Board. (2016). Islamic Financial Services Industry Stability Report 2016. Kuala Lumpur, Malaysia: Islamic Financial Services Board.

Jen, S. L. (2008). The GCC: Transforming oil wealth into financial portfolios. In J. Nugee, \& P. Subacchi (Eds.), The Gulf region: A new hub of global financial power (pp. 164-173). London: Chatham House.

Kuwait Investment Authority. (n. d.). Future Generations Fund. Retrieved from 
http://www.kia.gov.kw/en/ABOUTKIA/Pages/FGF.aspx

Masraf, A. R. (2016). Overview. Retrieved from https://www.alrayan.com/english/investor-relations/overview

Micklethwait, J. et al. (2016). Saudi Arabia plans US\$2 trillion mega fund for post-oil era: Deputy Crown Prince. Bloomberg News. Retrieved from http://www.bloomberg.com/news/articles/2016-04-01/saudi-arabia-plans-2-trillion-megafund-to-dwarf-all-it s-rivals

Mishrif, A. (2015). The political economy of Islamic banking and finance in the Gulf Cooperation Council countries. In M. Asutay, \& A. Turkistani (Eds.), Islamic finance: Political economy performance and risk (pp. 1-20). Berlin, Germany: Gerlach Books.

Monk, A. H. (2010). Sovereignty in the era of global capitalism: The rise of sovereign wealth funds and the power of finance. Environment and Planning, 43(8), 1813-1832. https://doi.org/10.1068/a43326

Mullally, W. (2016, May 26). The path forward. CPI financial. Retrieved from http://www.cpifinancial.net/features/category/islamic-finance/post/36179/the-path-forward

Mumtalakat. (n. d.). Portfolio. Retrieved from Mumtalakat: http://www.bmhc.bh/portfolio/sector\#1

Naqvi, S. N. H. (1995). Islam, economics and society. London: Kegan Paul International.

Neuman, W. L. (2015). Social research methods: Qualitative and quantitative approaches. Pearson.

Qatar International Islamic Bank. (n. d.). Bank Profile. Retrieved from http://www.qiib.com.qa/Page/Details/16

Qatar Investment Authority. (n. d.). Retrieved from http://www.ifswf.org/files/qatar-qiapdf-1

Ramady, M. (2014). Political, economic and financial country risk: analysis of the Gulf Cooperation Council. Cham: Springer. https://doi.org/10.1007/978-3-319-02177-5

Reisen, H. (2008). How to spend it: Distinguishing the origins of sovereign wealth funds. In J. Nugee \& P. Subacchi (Eds.), The Gulf region: A new hub of global financial power (pp. 194-202). London: Chatham House. https://doi.org/10.1787/242445844807

Saunders, M. et al. (2009). Research methods for business students. Harlow: Pearson Education Limited.

Seznec, J. F. (2012). The sovereign wealth funds of the Persian Gulf. In M. Kamrawa (Ed.), Political Economy of the Persian Gulf (pp. 69-94). London: C. Hurst \& Co.

SGFR. (n. d.). Our Investment. Retrieved from http://www.sgrf.gov.om/en/our-investments

Shabbir, T. (2009). Role of the Middle Eastern sovereign wealth funds in the current global financial crisis. Topics in Middle Eastern and North African Economies, 11.

Smith, D. K. (2009). Sovereign dilemmas: Saudi Arabia and sovereign wealth funds. Geopolitics, 14(2), 345-359. https://doi.org/10.1080/14650040902827831

Sovereign Wealth Fund Institute (SWFI). (June 2017). Sovereign Wealth Funds Rankings. Retrieved from http://www.swfinstitute.org/sovereign-wealth-fund-rankings/

Subacchi, P. (2008). Asian and Gulf sovereign wealth funds: A tale of two continents. In J. Nugee, \& P. Subacchi (Eds.), The Gulf region: A new hub of global financial power (pp. 149-162). London: Chatham House.

UK Trade \& Investment. (2014). UK excellence in Islamic finance. London: UK Trade \& Investment.

Wester, F. (1995). Strategieen voor Kwalitatief Onderzoek (Strategies for Qualitative Research) (3rd ed.). Muiderberg: Coutinho.

Wilson, R. (2009). The development of Islamic finance in the GCC (working paper). Kuwait Programme on Development, Governance and Globalization in the Gulf States. Retrieved from http://www.gslb.cimaglobal.com/Documents/Islamic\%20finance/2011/Press\%20cuttings/development-of-I F-in-the-GCC.pdf

\section{Copyrights}

Copyright for this article is retained by the author(s), with first publication rights granted to the journal.

This is an open-access article distributed under the terms and conditions of the Creative Commons Attribution license (http://creativecommons.org/licenses/by/4.0/). 